Canadian

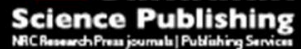

Canadian Journal of Physiology and Pharmacology Revue canadienne de physiologie et pharmacologie

\title{
Propofol attenuates BV2 microglia inflammation via NMDA receptor inhibition
}

\begin{tabular}{|c|c|}
\hline Journal: & Canadian Journal of Physiology and Pharmacology \\
\hline Manuscript ID & cjpp-2017-0243.R1 \\
\hline Manuscript Type: & Article \\
\hline Date Submitted by the Author: & 09-Jun-2017 \\
\hline Complete List of Authors: & $\begin{array}{l}\text { Wu, Qichao; Department of Anaesthesiology, Fudan University Shanghai } \\
\text { Cancer Centre, Department of Oncology, Shanghai Medical College, Fudan } \\
\text { University, Shanghai, P.R. China. } \\
\text { Zhao, Yanjun; Department of Anesthesiology, Shanghai Medical College, } \\
\text { Fudan University, Shanghai, China } \\
\text { Chen, Xiangyuan; Department of Anaesthesiology, Fudan University } \\
\text { Shanghai Cancer Centre, Department of Oncology, Shanghai Medical } \\
\text { College, Fudan University, Shanghai, P.R. China. } \\
\text { Zhu, Minmin; Department of Anesthesiology, Shanghai Medical College, } \\
\text { Fudan University, Shanghai, China. } \\
\text { Miao, Changhong; Department of Anesthesiology, Shanghai Medical } \\
\text { College, Fudan University, Shanghai, China }\end{array}$ \\
\hline $\begin{array}{r}\text { Is the invited manuscript for } \\
\text { consideration in a Special } \\
\text { Issue?: }\end{array}$ & N/A \\
\hline Keyword: & Propofol, BV2, LPS, CaMK II \\
\hline
\end{tabular}


Propofol attenuates BV2 microglia inflammation via NMDA receptor inhibition

Qichao $\mathrm{Wu}^{1,2 \#}$, Yanjun Zhao ${ }^{1 \#}$, Xiangyuan Chen ${ }^{1,2 \#}$, Minmin $\mathrm{Zhu}^{1 *}$, Changhong Miao ${ }^{1 *}$

${ }^{1}$ Department of Anaesthesiology, Fudan University Shanghai Cancer Centre, Shanghai, P.R. China.

2 Department of Anesthesiology, Shanghai Medical College, Fudan University, Shanghai, China.

* Corresponding Author

\# equal contributes

\section{Running Title: Propofol attenuates BV2 inflammation}

\section{Corresponding author:}

Minmin Zhu, Ph.D., Changhong Miao, Ph.D.

Fudan University Shanghai Cancer Center

Department of Anaesthesiology

No.270 DongAn Road, Shanghai, 200032, P.R.China.

Phone: 86-21-64175590

E-mail address: zhu_mm@126.com 
E-mail address: miao_chh@126.com 


\section{ABSTRACT}

Activated microglia, involved in the occurrence and improvement of sepsis-associated encephalopathy, can induce the expression of pro-inflammatory cytokines and pro-inflammatory enzymes, resulting in inflammation-mediated neuronal cell death. It was reported that propofol could inhibit lipopolysaccharide (LPS)-induced pro-inflammatory cytokines and pro-inflammatory enzymes expression in BV2 and primary microglial cells. However, the underlying mechanism is not well known. In the present study, we investigated whether and how propofol inhibited LPS-induced the expression of pro-inflammatory cytokines and pro-inflammatory enzymes in BV2 cells. LPS induced pro-inflammatory cytokines and pro-inflammatory enzymes expression, NF- $\mathrm{B}$, extracellular regulated kinase $1 / 2$ (ERK) and Calcium $\left(\mathrm{Ca}^{2+}\right) /$ calmodulin-dependent protein kinase $\quad$ II $\quad(\mathrm{CaMK} \quad$ II) phosphorylation, and $\mathrm{BV} 2$ cells $\mathrm{Ca}^{2+}$ accumulation. Propofol could reverse these effects induced by LPS. MK801, an inhibitor of NMDA receptor, could attenuate LPS-induced $\mathrm{Ca}^{2+}$ accumulation, the expression of pro-inflammatory cytokines and pro-inflammatory enzymes, phosphorylation of NF- $\mathrm{B}$, ERK and CaMK II, which was similar with propofol. Moreover, these effects of propofol could be counteracted by rapastinel, an activator of NMDA receptor. The present study suggested that propofol, via inhibiting NMDA receptor, attenuating $\mathrm{Ca}^{2+}$ 
accumulation, inhibiting CaMK II, ERK1/2 and NF- $\mathrm{kB}$ phosphorylation, down-regulated LPS-induced pro-inflammatory cytokines and pro-inflammatory enzymes expression.

Key words: Propofol, BV2, LPS, CaMK II. 


\section{INTRODUCTION}

Sepsis-associated encephalopathy acts as brain dysfunction induced by a systemic inflammation without a direct brain infection in critically ill patients (Girard et al. 2010; Gofton and Young 2012; Iwashyna et al. 2012), and it is a common syndrome, which is associated with an increased rate of morbidity and mortality in sepsis patients. It is reported that microglia activation is involved in the occurrence and progression of sepsis-associated encephalopathy (Michels et al. 2015). Activated microglia can induce the expression of pro-inflammatory cytokines such as tumor necrosis factor $\alpha$ (TNF- $\alpha$ ), interleukin-1 (IL-1) and interleukin-6 (IL-6) (Michels et al. 2015), and pro-inflammatory enzymes such as inducible nitric oxide synthase (iNOS) and cyclooxygenase II (COX II) (Fu et al. 2014), resulting in inflammation-mediated neuronal cell death. Studies have indicated that extracellular regulated kinase 1/2 (ERK1/2) and NF- $\kappa \mathrm{B}$ activation plays an important role in pro-inflammatory enzymes and cytokines expression in LPS-treated BV2 cells (a microglia cell line) (Liu et al. 2014; Matsuda et al. 2003; Sakon et al. 2003).

The intravenous general anesthetic propofol is frequently employed for the sedation of critically ill patients. Previous studies indicated that propofol could inhibited lipopolysaccharide (LPS)-induced the expression of pro-inflammatory cytokines and pro-inflammatory enzymes in BV2 and primary microglial cells (Luo et al. 2013; Peng et al. 2014). However, 
the underlying mechanisms by which propofol inhibited LPS-induced pro-inflammatory cytokines and pro-inflammatory enzymes expression have not been well studied. In the present study, we investigated whether and how propofol inhibited LPS-induced the expression of pro-inflammatory cytokines and pro-inflammatory enzymes in BV2 cells. 


\section{MATERIALS AND METHODS}

\section{Cell culture and reagent}

BV2 cells were cultured in DMEM and 10\% fetal bovine serum in incubator containing $5 \% \mathrm{CO}_{2}$ at $37{ }^{\circ} \mathrm{C}$. Cells were sub-cultured when reaching $90 \%$ confluence.

KN93 (an inhibitor of CaMK II), MK801 (an inhibitor of NMDA receptor) and rapastinel (an activator of NMDA receptor), were purchased form Sigma (St. Louis, MO)

\section{Study design}

Cells were cultured with $1 \mu \mathrm{g} / \mathrm{ml}$ LPS for $6 \mathrm{~h}$. At the end of $4 \mathrm{~h}$ incubation, cells were co-incubated with different concentrations $(5,25$, 50 and $100 \mu \mathrm{M})$ of propofol for the last $2 \mathrm{~h}$. The optimal concentration of propofol with significant inhibitory effects on pro-inflammatory cytokines and pro-inflammatory enzymes expression was determined. These treatment conditions were used in the following studies in which cells were cultured and divided into six groups to examine the underlying signaling pathways. Group 1: cells were cultured in DMEM as control; Group 2: cells were treated with $1 \mu \mathrm{g} / \mathrm{ml}$ LPS for 6h; Group 3: cells were treated with LPS for $4 \mathrm{~h}$, followed by co-incubation with $50 \mu \mathrm{M}$ propofol for the last 2h; Group 4: cells were treated with LPS for 4h, followed by 
co-incubation with $10 \mu \mathrm{M}$ KN93 for the last 2h; Group 5: cells were treated with LPS for $4 \mathrm{~h}$, followed by co-incubation with $25 \mu \mathrm{M}$ MK801 for the last 2h; Group 6: cells were treated with LPS for $4 \mathrm{~h}$, followed by co-incubation with $50 \mu \mathrm{M}$ propofol and $10 \mu \mathrm{M}$ rapastinel for the last $2 \mathrm{~h}$.

\section{Real-time quantitative RT-PCR}

Total RNA extracts were prepared with the use of trizol (Invitrogen). mRNA was reverse transcribed using the PrimeScript ${ }^{\mathrm{TM}}$ RT reagent Kit (TaKaRa). Real-time PCR was performed using the Applied Biosystems HT7900 PCR system with $2 \times$ QuantiFast SYBR Green PCR Master Mix (Qiagen), $0.2 \mu \mathrm{mol} / \mathrm{L}$ primers, and $<1 \mu \mathrm{g}$ cDNA in a $10 \mu \mathrm{L}$ reaction mixture. The oligonucleotide primers for $\beta$-actin were CTGTCCCTGTATGCCTCTG (forward) and ATGTCACGCACGATTTCC (reverse); for COXII were TGAGTACCGCAAACGCTTCTC (forward) and TGGACGAGGTTTTTCCACCAG (reverse); for iNOS were CAGCTGGGCTGTACAAACCTT (forward) and CATTGGAAGTGAAGCGTTTCG (reverse); for IL-1 $\beta$ were GAAATGCCACCTTTTGACAGTG (forward) and TGGATGCTCTCATCAGGACAG (reverse); for IL-6 were CCAATGCTCTCCTAACAGAT (forward) and TGTCCACAAACTGATATGCT (reverse); for IL-1 $\alpha$ were 
ACGTCAAGCAACGGGAAGAT

(forward)

and

AAGGTGCTGATCTGGGTTGG (reverse) ; for TNF- $\alpha$ were ACTCTGACCCCTTTACTCTG

(forward)

and

GAGCCATAATCCCCTTTCTA (reverse). The data were expressed as fold increase compared with control group.

\section{Western Blot Analysis}

Protein extracts were prepared with the use of cell lysis buffer (Cell Signaling Technology, Danvers, MA). Equal amount of protein extracted from different groups of cells was separated by 8 or $10 \%$ SDS-PAGE and transferred to PVDF membranes. After being blocked in $5 \%$ skim milk, the membranes were incubated with correspondent primary antibody at 4 ${ }^{\circ} \mathrm{C}$ for overnight. The primary antibodies used were monoclonal antibody against $\beta$-actin (catalog sc-70319, Santa Cruz Biotechnology, Santa Cruz, CA), NMDA receptors GluN2B subunit (NMDA R2B) (catalog 4207, Cell Signaling Technology, Danvers, MA), p-ERK1/2 (catalog sc-81492, Santa Cruz Biotechnology, Santa Cruz, CA), ERK1/2 (catalog 4695, Cell Signaling Technology, Danvers, MA), Calcium $\left(\mathrm{Ca}^{2+}\right) /$ calmodulin-dependent protein kinase II (CaMK II) (catalog ab195518, Abcam, Cambridge, UK), p-CaMK II (catalog 12716, Cell Signaling Technology, Danvers, MA), NF-кB (catalog 4764, Cell Signaling Technology, Danvers, MA), p-NF-кB (catalog 3033, Cell 
Signaling Technology, Danvers, MA). Thereafter, the primary antibodies were washed away, and the membranes were incubated with secondary antibodies for $1 \mathrm{~h}$ at room temperature. Subsequently, the membranes were washed and detected by the ECL system. The respective densities of the protein bands were analyzed by UN SCAN-IT gel software. In the present study, $\beta$-actin was used as loading control in protein extracts.

\section{$\mathrm{Ca}^{2+}$ concentration assay}

Cells $\mathrm{Ca}^{2+}$ concentration was detected by the Calcium Detection Kit (Abcam, Cambridge, UK) according to the datasheet. Briefly, after being washed by cold PBS, cells were re-suspended in $500 \mu \mathrm{L}$ of Calcium Assay Buffer and homogenized quickly by pipetting up and down a few times. The supernatant were collected by centrifuge and transferred to a clean tube. After adding $90 \mu \mathrm{L}$ of the Chromogenic Reagent and $60 \mu \mathrm{L}$ of Calcium Assay Buffer into each well, the mixture was incubate at room temperature for 5-10 minutes protected from light. The absorbance was read at $575 \mathrm{~nm}$ spectrophotometrically and the data was expressed as the percentage of the control group.

\section{Statistical Analysis}

Data were obtained from 5 separately performed experiments and are expressed as mean $\pm \mathrm{SD}$. $\mathrm{N}$ represents the times of repeated 
experiments using different cell cultures.

Statistical comparison was performed with one-way analysis of variance followed with Bonferroni-corrected pairwise comparisons using GraphPad Prism 5.0 software (San Diego, CA, USA). A post hoc value of $\mathrm{P}<0.05$ was considered significant. 


\section{RESULTS}

Propofol inhibits LPS-induced pro-inflammatory cytokines and pro-inflammatory enzymes expression.

In BV2 cells, compared with control group, LPS caused a marked increase of COX II, iNOS, IL- $1 \alpha$, IL-1 $\beta$, IL-6 and TNF- $\alpha$ expression (Figure 1, $\mathrm{p}<0.05$ ). We also found that propofol could attenuate LPS-induced the expression of pro-inflammatory cytokines and pro-inflammatory enzymes in a concentration-dependent manner. Incubation of cells with $50 \mu \mathrm{M}$ propofol for 2 hours caused a significant inhibition of LPS-induced pro-inflammatory cytokines and pro-inflammatory enzymes expression (Figure 1, $<<0.05$ compared with LPS treatment).

Propofol inhibits LPS-induced phosphorylation of $N F-\kappa B$ and ERK1/2.

Compared with control group, LPS up-regulated NF-אB and ERK1/2 phosphorylation (Figure 2, $\mathrm{p}<0.05$ ). Moreover, propofol could attenuate these effects of LPS in a concentration-dependent manner. Incubation of cells with $50 \mu \mathrm{M}$ propofol for 2 hours caused a significant inhibition of LPS-induced NF- $\mathrm{kB}$ and ERK1/2 phosphorylation (Figure 2, $\mathrm{p}<0.05$ compared with LPS treatment).

Propofol inhibits LPS-induced phosphorylation of CaMK II and $\mathrm{Ca}^{2+}$ accumulation. 
Compared with control group, LPS up-regulated CaMK II phosphorylation (Figure $3 \mathrm{~A}-\mathrm{B}, \mathrm{p}<0.05$ ) and increased $\mathrm{Ca}^{2+}$ concentration (Figure 3C, $\mathrm{p}<0.05$ ). Moreover, propofol could reverse these effects of LPS in a concentration-dependent manner. Incubation of cells with $50 \mu \mathrm{M}$ propofol for 2 hours caused a significant inhibition of LPS-induced CaMK II phosphorylation (Figure 3A-B, $\mathrm{p}<0.05$ compared with LPS treatment) and $\mathrm{Ca}^{2+}$ accumulation (Figure 3C, $\mathrm{p}<0.05$ compared with LPS treatment).

This treatment condition of propofol was used in the following experiments to explore the signaling pathways responsible for the protective effects of propofol.

LPS-mediated CaMK II phosphorylation and $\mathrm{Ca}^{2+}$ accumulation, and its modulation by propofol, KN93, MK801 and rapastinel.

The expression of NMDA R2B was not effected by Propofol, KN93, MK801 and rapastinel ( Figure 4A-B).

KN93, an inhibitor of CaMK II, attenuated LPS-induced CaMK II phosphorylation (Figure 4A, C, p<0.05 compared with LPS treatment), which was similar with propofol. However, KN93 did not affect LPS-mediated $\mathrm{Ca}^{2+}$ accumulation (Figure 4D).

MK801, an inhibitor of NMDA receptor, attenuated LPS-induced CaMK II phosphorylation (Figure 4A, C, p $<0.05$ compared with LPS treatment) and $\mathrm{Ca}^{2+}$ accumulation (Figure 4D, $\mathrm{p}<0.05$ compared with LPS 
treatment), which was similar with propofol. Moreover, the effects of propofol could be reversed by rapastinel, an activator of NMDA receptor (Figure 4A, C, D).

LPS-mediated ERKI/2 and NF- $\kappa B$ phosphorylation, and its Modulation by propofol, KN93, MK801 and rapastinel.

KN93 and MK801 inhibited LPS-induced ERK1/2 and NF- $\mathrm{B}$ phosphorylation (Figure 5A-C, $\mathrm{p}<0.05$ compared with LPS treatment), which was similar with propofol. Moreover, the effects of propofol could be counteracted by rapastinel (Figure 5A-C).

LPS-mediated pro-inflammatory cytokines and pro-inflammatory enzymes expression, and its modulation by Propofol, KN93, MK801 and rapastinel.

KN93 and MK801 inhibited LPS-mediated the expression of pro-inflammatory cytokines and pro-inflammatory enzymes (Figure 6, $\mathrm{p}<0.05$ compared with LPS treatment), which was similar with propofol. Moreover, the effects of propofol could be inhibited by rapastinel (Figure $6)$. 


\section{DISCUSSION}

In the present study, we found that propofol could inhibit LPS-induced BV2 cells inflammation via attenuating LPS-mediated expression of pro-inflammatory cytokines and pro-inflammatory enzymes. Our data also suggested that the protective effects of propofol might be achieved by inhibiting NMDA receptor, inhibiting LPS-mediated $\mathrm{Ca}^{2+}$ accumulation, and attenuating LPS-induced phosphorylation of CaMK II, ERK1/2 and NF- $\kappa B$.

Previous studies indicated that ERK1/2 and NF- $\mathrm{KB}$ activation plays an important role in the LPS-induced expressions of pro-inflammatory enzymes and pro-inflammatory cytokines in microglia and BV2 cells (Liu et al. 2014; Matsuda et al. 2003; Sakon et al. 2003). These results were quite similar with ours. In the present study we found LPS up-regulated CaMK II phosphorylation. Moreover, KN93, a CaMK II inhibitor, could inhibit LPS-induced ERK1/2 and NF- $\mathrm{B}$ phosphorylation. These data suggested that CaMK II is the upstream of ERK1/2 and NF- $\kappa \mathrm{B}$ in LPS-induced BV2 cells activation. $\mathrm{Ca}^{2+}$ could regulate the activities of CaMKs which are multifunctional serine/threonine kinases (Hook and Means 2001). Previous studies indicated that LPS increased $\mathrm{Ca}^{2+}$ accumulation in BV2 cells (Yuan et al. 2016). In the present study, we also found LPS could increase BV2 cells $\mathrm{Ca}^{2+}$ concentration, which may in turn up-regulate CaMK II phosphorylation, thus inducing ERK1/2 and 
NF- $\kappa \mathrm{B}$ phosphorylation, leading to BV2 cells activation.

Propofol is an intravenous anesthetic agent which is widely used for the sedation of critically ill patients. Previous studies indicated that propofol inhibited LPS-induced pro-inflammatory enzymes and pro-inflammatory cytokines expression in BV2 cells (Luo et al. 2013; Peng et al. 2014), which was similar with the present study. However, the neuro-protective function of propofol was not well recognized. Propofol exerts its effects by activating $\mathrm{GABA}_{\mathrm{A}}$ receptor (Mohammadi et al. 2001; Reiner et al. 2013) and inhibiting NMDA receptor (Irifune et al. 2003) in central nervous system (CNS). Previous study indicated that $\mathrm{GABA}_{\mathrm{A}}$ receptor agonist bicuculline or picrotoxin did not reverse the inhibition effect of propofol on LPS-mediated BV2 cells activation (Luo et al. 2013; Peng et al. 2014). These data was quite similar with our pre-experiments (data not shown). So we further explored whether NMDA receptor participated in the protective effect of propofol. NMDA receptors widely exist in CNS (Shibuta et al. 2001; Trapani et al. 2000). In the present study NMDA receptor was also found to be expressed in the BV2 cells (Figure 4A). NMDA R2B has been found to exhibit a main channel function in brain (Carroll and Zukin 2002; Sobczyk et al. 2005). Activation of NMDA receptors containing GluN2B subunit causes $\mathrm{Ca}^{2+}$ influx (Carroll and Zukin 2002), thus increasing intracellular $\mathrm{Ca}^{2+}$ concentration. $\mathrm{Ca}^{2+}$ could regulate the activities of CaMKs which are 
multifunctional serine/threonine kinases (Hook and Means 2001). Propofol was reported to inhibit NMDA subtype of glutamate receptor via an allosteric modulation of channel gating, thus decreased the probability of cannel opening (Orser et al. 1995). In the present study, the expression of NMDA R2B was not affect by propofol, however we found propofol inhibited LPS-induced $\mathrm{Ca}^{2+}$ accumulation and CaMK II phosphorylation, thus attenuating LPS-mediated BV2 cells activation. Our study also indicated that the protective effect of propofol is similar with MK801, an inhibitor of NMDA receptor. Moreover, the protective effects of propofol could be reversed by rapastinel, an activator of NMDA receptor. These result strongly indicated that the protective effects of propofol on LPS-mediated BV2 cells inflammation was achieved by inhibition of NMDA receptor.

In the present study, 50uM Propofol was found to attenuate LPS-induced BV2 cells inflammation. In patients, the brain concentrations of propofol during anesthesia ranged from 11 to $33 \mu \mathrm{M}$ (Ellerkmann et al. 2004; Iannuzzi et al. 2005; Kreuer et al. 2004), and high concentrations of propofol could be more damaging than beneficial. However, it was reported that in murine the concentration of propofol in whole brain during anesthesia is about $75 \mu \mathrm{M}$ (Shyr et al. 1995). In the present study, we used BV2, which is a murine microglia cell line. Therefore, in this study, $50 \mu \mathrm{M}$ propofol was considered to be an 
appreciate concentration of propofol to study the protective effect of propofol against LPS-induced inflammation in BV2 cells. However, the present study needs to be further confirmed by in vivo study.

The present study has some limitations. First, the study was carried out in BV2 cells, which is an in vitro system. It differs from in vivo settings, especially considering effectiveness and toxicity of medicine. Second, BV2-HT22 neuronal co-culture was not used to evaluate the effects of propofol on inflammation-induced neuronal death. Further studies using BV2-HT22 neuronal co-culture are necessary to clarify these issues.

In summary, the present study suggested that LPS, by inducing $\mathrm{Ca}^{2+}$ accumulation, CaMK II, ERK1/2 and NF- $\mathrm{BB}$ phosphorylation, up-regulated the expression of pro-inflammatory cytokines and pro-inflammatory enzymes. Importantly, our study demonstrated that propofol, via inhibiting NMDA receptor, attenuating $\mathrm{Ca}^{2+}$ accumulation, inhibiting CaMK II, ERK1/2 and NF- $\mathrm{kB}$ phosphorylation, down-regulated LPS-induced the expression of pro-inflammatory cytokines and pro-inflammatory enzymes. Our data implied the potential advantage of the administration of propofol to provide sedation and cerebral protection in sepsis patients in intensive care unit. 


\section{ACKNOWLEDGMENTS}

Funding: This work was supported by the national natural science foundation of China (No. NSFC1313).

The co-authors have read the manuscript and approved its submission to Canadian journal of physiology and pharmacology.

\section{CONFLICT OF INTEREST}

None. 


\section{REFERENCES}

Carroll, R.C., and Zukin, R.S. 2002. NMDA-receptor trafficking and targeting: implications for synaptic transmission and plasticity. Trends in neurosciences 25(11): 571-577.

Ellerkmann, R.K., Kreuer, S., Wilhelm, W., Wenningmann, I., Roepcke, H., Hoeft, A., and Bruhn, J. 2004. The correlation of the bispectral index with propofol effect site concentrations is not altered by epochs indicated as artefact-loaded by narcotrend. Journal of clinical monitoring and computing 18(4):

283-287.

Fu, S.P., Li, S.N., Wang, J.F., Li, Y., Xie, S.S., Xue, W.J., Liu, H.M., Huang, B.X., Lv, Q.K., Lei, L.C., Liu, G.W., Wang, W., and Liu, J.X. 2014. BHBA suppresses LPS-induced inflammation in BV-2 cells by inhibiting NF-kappaB activation. Mediators of inflammation 2014: 983401. doi: 10.1155/2014/983401. Girard, T.D., Jackson, J.C., Pandharipande, P.P., Pun, B.T., Thompson, J.L., Shintani, A.K., Gordon, S.M., Canonico, A.E., Dittus, R.S., Bernard, G.R., and Ely, E.W. 2010. Delirium as a predictor of long-term cognitive impairment in survivors of critical illness. Crit Care Med 38(7): 1513-1520. doi: 10.1097/CCM.0b013e3181e47be1.

Gofton, T.E., and Young, G.B. 2012. Sepsis-associated encephalopathy. Nature Reviews Neurology 8(10): 557-566.

Hook, S.S., and Means, A.R. 2001. Ca2+/CaM-dependent kinases: from activation to function. Annual review of pharmacology and toxicology 41(1): 471-505.

Iannuzzi, M., Iannuzzi, E., Rossi, F., Berrino, L., and Chiefari, M. 2005. Relationship between bispectral index, electroencephalographic state entropy and effect-site EC50 for propofol at different clinical endpoints. British journal of anaesthesia 94(4): 492-495.

Irifune, M., Takarada, T., Shimizu, Y., Endo, C., Katayama, S., Dohi, T., and Kawahara, M. 2003. Propofol-induced anesthesia in mice is mediated by gamma-aminobutyric acid-A and excitatory amino acid receptors. Anesth Analg 97(2): 424-429, table of contents.

Iwashyna, T.J., Cooke, C.R., Wunsch, H., and Kahn, J.M. 2012. Population burden of long-term survivorship after severe sepsis in older Americans. Journal of the American Geriatrics Society 60(6): 1070-1077. doi: 10.1111/j.1532-5415.2012.03989.x.

Kreuer, S., Wilhelm, W., Grundmann, U., Larsen, R., and Bruhn, J. 2004. Narcotrend index versus bispectral index as electroencephalogram measures of anesthetic drug effect during propofol anesthesia. Anesthesia \& Analgesia 98(3): 692-697.

Liu, R.P., Zou, M., Wang, J.Y., Zhu, J.J., Lai, J.M., Zhou, L.L., Chen, S.F., Zhang, X., and Zhu, J.H. 2014. Paroxetine ameliorates lipopolysaccharide-induced microglia activation via differential regulation of MAPK signaling. Journal of neuroinflammation 11: 47. doi: 10.1186/1742-2094-11-47.

Luo, T., Wu, J., Kabadi, S.V., Sabirzhanov, B., Guanciale, K., Hanscom, M., Faden, J., Cardiff, K., Bengson, C.J., and Faden, A.I. 2013. Propofol limits microglial activation after experimental brain trauma through inhibition of nicotinamide adenine dinucleotide phosphate oxidase. Anesthesiology 119(6): 1370-1388. doi: 10.1097/aln.0000000000000020.

Matsuda, A., Suzuki, Y., Honda, G., Muramatsu, S., Matsuzaki, O., Nagano, Y., Doi, T., Shimotohno, K., Harada, T., Nishida, E., Hayashi, H., and Sugano, S. 2003. Large-scale identification and characterization of human genes that activate NF-kappaB and MAPK signaling pathways. Oncogene 22(21): 3307-3318. doi: 10.1038/sj.onc.1206406.

Michels, M., Vieira, A.S., Vuolo, F., Zapelini, H.G., Mendonca, B., Mina, F., Dominguini, D., Steckert, A., Schuck, P.F., Quevedo, J., Petronilho, F., and Dal-Pizzol, F. 2015. The role of microglia activation in the 
development of sepsis-induced long-term cognitive impairment. Brain Behav Immun 43: 54-59. doi: 10.1016/j.bbi.2014.07.002.

Mohammadi, B., Haeseler, G., Leuwer, M., Dengler, R., Krampfl, K., and Bufler, J. 2001. Structural requirements of phenol derivatives for direct activation of chloride currents via GABA A receptors. European journal of pharmacology 421(2): 85-91.

Orser, B.A., Bertlik, M., Wang, L.Y., and MacDonald, J.F. 1995. Inhibition by propofol (2, 6 di isopropylphenol) of the $\mathrm{N}$ - methyl - D - aspartate subtype of glutamate receptor in cultured hippocampal neurones. British journal of pharmacology 116(2): 1761-1768.

Peng, M., Ye, J.S., Wang, Y.L., Chen, C., and Wang, C.Y. 2014. Posttreatment with propofol attenuates lipopolysaccharide-induced up-regulation of inflammatory molecules in primary microglia.

Inflammation research : official journal of the European Histamine Research Society ... [et al.] 63(5): 411-418. doi: 10.1007/s00011-014-0713-9.

Reiner, G.N., Perillo, M.A., and García, D.A. 2013. Effects of propofol and other GABAergic phenols on membrane molecular organization. Colloids and Surfaces B: Biointerfaces 101: 61-67.

Sakon, S., Xue, X., Takekawa, M., Sasazuki, T., Okazaki, T., Kojima, Y., Piao, J.H., Yagita, H., Okumura, K., Doi, T., and Nakano, H. 2003. NF-kappaB inhibits TNF-induced accumulation of ROS that mediate prolonged MAPK activation and necrotic cell death. The EMBO journal 22(15): 3898-3909. doi: 10.1093/emboj/cdg379.

Shibuta, S., Sriranganathan, V., Inoue, T., Shimizu, T., Tomi, K., and Mashimo, T. 2001. The effects of propofol on NMDA-or nitric oxide-mediated neurotoxicity in vitro. Neuroreport 12(2): 295-298.

Shyr, M.-H., Tsai, T.-H., Tan, P.P., Chen, C.-F., and Chan, S.H. 1995. Concentration and regional distribution of propofol in brain and spinal cord during propofol anesthesia in the rat. Neuroscience letters 184(3): 212-215.

Sobczyk, A., Scheuss, V., and Svoboda, K. 2005. NMDA receptor subunit-dependent [Ca2+] signaling in individual hippocampal dendritic spines. Journal of Neuroscience 25(26): 6037-6046.

Trapani, G., Altomare, C., Sanna, E., Biggio, G., and Liso, G. 2000. Propofol in anesthesia. Mechanism of action, structure-activity relationships, and drug delivery. Current medicinal chemistry 7(2): 249-271. Yuan, L., Liu, S., Bai, X., Gao, Y., Liu, G., Wang, X., Liu, D., Li, T., Hao, A., and Wang, Z. 2016. Oxytocin inhibits lipopolysaccharide-induced inflammation in microglial cells and attenuates microglial activation in lipopolysaccharide-treated mice. Journal of neuroinflammation 13(1): 77. doi:

10.1186/s12974-016-0541-7. 


\section{LEGEND TO FIGURES}

Figure 1. Propofol inhibits LPS-induced pro-inflammatory cytokines and pro-inflammatory enzymes expression. BV2 cells were treated with $1 \mu \mathrm{g} / \mathrm{ml}$ LPS for $4 \mathrm{~h}$, followed by co-incubation with different concentration $(5,25,50,100 \mu \mathrm{M})$ of propofol for the last $2 \mathrm{~h}$. (A-F) Propofol attenuated LPS-induced the expression of pro-inflammatory cytokines and pro-inflammatory enzymes in a concentration-dependent manner. Incubation of cells with $50 \mu \mathrm{M}$ propofol for 2 hours caused a significant inhibition of LPS-induced pro-inflammatory cytokines and pro-inflammatory enzymes expression. Propofol solvent dimethyl sulfoxide (DMSO) did not affect LPS-induced the expression of pro-inflammatory cytokines and pro-inflammatory enzymes. $\left({ }^{*} \mathrm{P}<0.05\right.$ vs. control, $\# \mathrm{P}<0.05$ vs. LPS treatment, $\mathrm{n}=5$. Data are shown as mean \pm SD.)

Figure 2. Propofol inhibits LPS-induced phosphorylation of NF-kB and ERK1/2. BV2 cells were treated with $1 \mu \mathrm{g} / \mathrm{ml}$ LPS for $4 \mathrm{~h}$, followed by co-incubation with different concentration $(5,25,50,100 \mu \mathrm{M})$ of propofol for the last 2h. (A) Equal amounts of proteins were separated by SDS-PAGE and immunoblotted with antibodies to $\mathrm{p}-\mathrm{NF}-\kappa \mathrm{B}, \mathrm{NF}-\kappa \mathrm{B}$, p-ERK1/2 and ERK1/2. (B) The protein expression ratio of p-NF- $\kappa B$ and NF-KB. The ratio in the control group was set as 1. (C) The protein 
expression ratio of $\mathrm{p}-\mathrm{ERK} 1 / 2$ and ERK1/2. The ratio in the control group was set as 1 . $\left({ }^{*} \mathrm{P}<0.05\right.$ vs. control, $\# \mathrm{P}<0.05$ vs. LPS treatment, $\mathrm{n}=5$. Data are shown as mean $\pm \mathrm{SD}$.)

Figure 3. Propofol inhibits LPS-induced phosphorylation of CaMK II and $\mathrm{Ca}^{2+}$ accumulation. BV2 cells were treated with $1 \mu \mathrm{g} / \mathrm{ml}$ LPS for $4 \mathrm{~h}$, followed by co-incubation with different concentration $(5,25,50,100 \mu \mathrm{M})$ of propofol for the last 2h. (A) Equal amounts of proteins were separated by SDS-PAGE and immunoblotted with antibodies to p-CaMK II and CaMK II. (B) The protein expression ratio of p-CaMK II and CaMK II. The ratio in the control group was set as 1. (C) propofol inhibited LPS-mediated $\mathrm{Ca}^{2+}$ accumulation in a concentration-depend manner. (*P $<0.05$ vs. control, $\# \mathrm{P}<0.05$ vs. LPS treatment, $\mathrm{n}=5$. Data are shown as mean \pm SD.)

Figure 4. LPS-mediated CaMK II phosphorylation and $\mathrm{Ca}^{2+}$ accumulation, and its modulation by propofol, KN93, MK801 and rapastinel. BV2 cells were treated with $1 \mu \mathrm{g} / \mathrm{ml}$ LPS for $4 \mathrm{~h}$, followed by co-incubation with propofol, KN93, MK801 or propofol plus repastinel for the last 2h. (A) Equal amounts of proteins were separated by SDS-PAGE and immunoblotted with antibodies to NMDA R2B, CaMK II and p-CaMK II. (B) The protein expression ratio of NMDA R2B and 
$\beta$-actin. The ratio in the control group was set as 1. (C) The protein expression ratio of $\mathrm{p}-\mathrm{CaMK}$ II and CaMK II. The ratio in the control group was set as 1. (D) propofol inhibited LPS-mediated $\mathrm{Ca}^{2+}$ accumulation, which was similar to MK801. Moreover, the effect of propofol could be counteracted by rapastinel. KN93 had no effect on cells $\mathrm{Ca}^{2+}$ concentration. ( ${ }^{*} \mathrm{P}<0.05$ vs. control, \#P $<0.05$ vs. LPS treatment, $\& \mathrm{P}<0.05$ vs. propofol treatment, $\mathrm{n}=5$. Data are shown as mean \pm SD.)

Figure 5. LPS-mediated ERK1/2 and NF-אB phosphorylation, and its modulation by propofol, KN93, MK801 and rapastinel. BV2 cells were treated with $1 \mu \mathrm{g} / \mathrm{ml}$ LPS for $4 \mathrm{~h}$, followed by co-incubation with propofol, KN93, MK801 or propofol plus repastinel for the last 2h. (A) Equal amounts of proteins were separated by SDS-PAGE and immunoblotted with antibodies to p-NF- $\mathrm{B}, \mathrm{NF}-\kappa \mathrm{B}, \mathrm{p}-\mathrm{ERK} 1 / 2$ and ERK1/2. (B) The protein expression ratio of $p-N F-\kappa B$ and NF- $\kappa B$. The ratio in the control group was set as 1 . (C) The protein expression ratio of p-ERK1/2 and ERK1/2. The ratio in the control group was set as $1 .\left({ }^{*} \mathrm{P}<\right.$ 0.05 vs. control, $\# \mathrm{P}<0.05$ vs. LPS treatment, $\& \mathrm{P}<0.05$ vs. propofol treatment, $\mathrm{n}=5$. Data are shown as mean $\pm \mathrm{SD}$.)

Figure 6. LPS-induced pro-inflammatory cytokines and pro-inflammatory enzymes expression, and its modulation by 
propofol, KN93, MK801 and rapastinel. BV2 cells were treated with $1 \mu \mathrm{g} / \mathrm{ml}$ LPS for $4 \mathrm{~h}$, followed by co-incubation with propofol, KN93, MK801 or propofol plus repastinel for the last 2h. (A-F) Propofol inhibited LPS-induced the expression of pro-inflammatory cytokines and pro-inflammatory enzymes, which was similar to KN93 and MK801. Moreover, the effect of propofol could be counteracted by rapastinel. (*P $<0.05$ vs. control, \#P $<0.05$ vs. LPS treatment, $\& \mathrm{P}<0.05$ vs. propofol treatment, $\mathrm{n}=5$. Data are shown as mean $\pm \mathrm{SD}$.) 


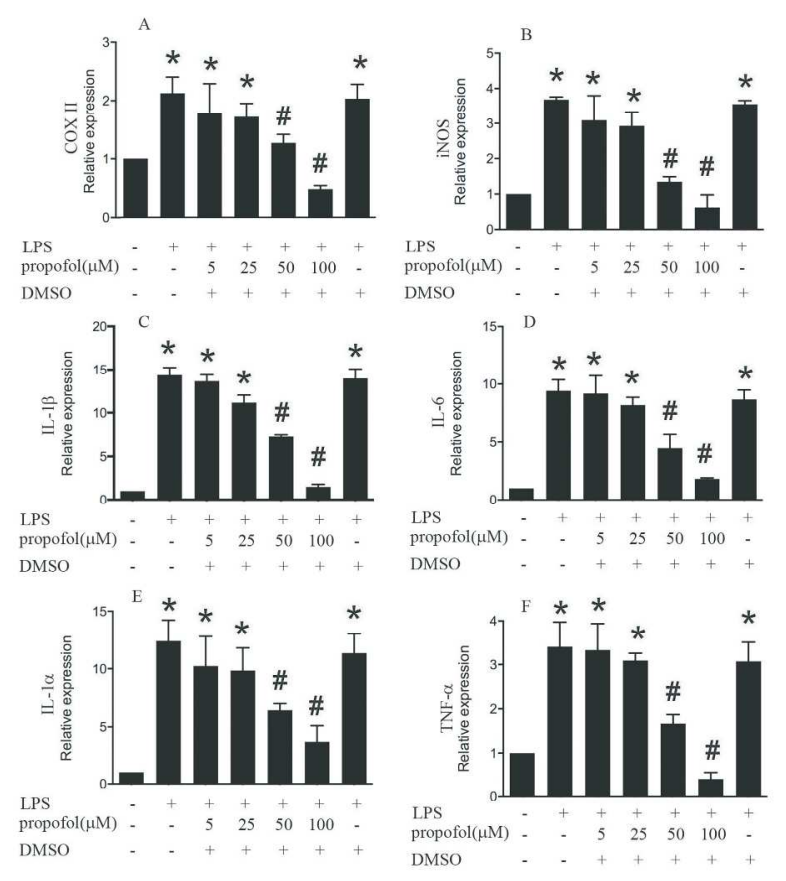

Figure 1. Propofol inhibits LPS-induced pro-inflammatory cytokines and pro-inflammatory enzymes expression. BV2 cells were treated with $1 \mu \mathrm{g} / \mathrm{ml}$ LPS for $4 \mathrm{~h}$, followed by co-incubation with different concentration $(5,25,50,100 \mu \mathrm{M})$ of propofol for the last $2 \mathrm{~h}$. (A-F) Propofol attenuated LPS-induced the expression of pro-inflammatory cytokines and pro-inflammatory enzymes in a concentration-dependent manner. Incubation of cells with $50 \mu \mathrm{M}$ propofol for 2 hours caused a significant inhibition of LPS-induced pro-inflammatory cytokines and pro-inflammatory enzymes expression. Propofol solvent dimethyl sulfoxide (DMSO) did not affect LPS-induced the expression of pro-inflammatory cytokines and pro-inflammatory enzymes. ( $* P<0.05$ vs. control, $\# P<0.05$ vs. LPS treatment, $n=5$. Data are shown as mean $\pm S D$.) 
A

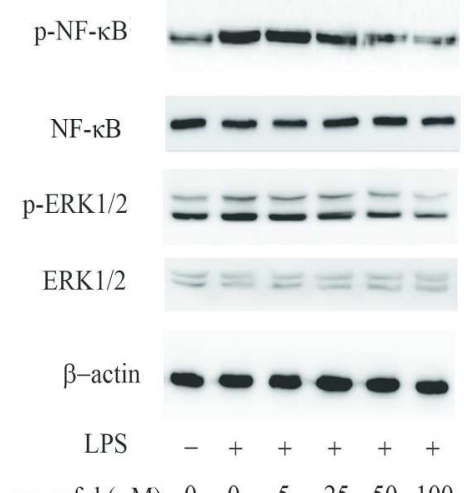

propofol $(\mu \mathrm{M}) \quad 0 \quad 0 \quad 5 \quad 25 \quad 50 \quad 100$

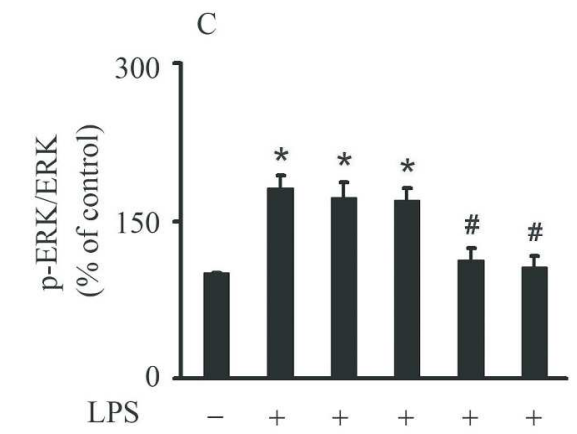

propofol $(\mu \mathrm{M}) \quad 0 \quad 0 \quad 5 \quad 25 \quad 50 \quad 100$
B

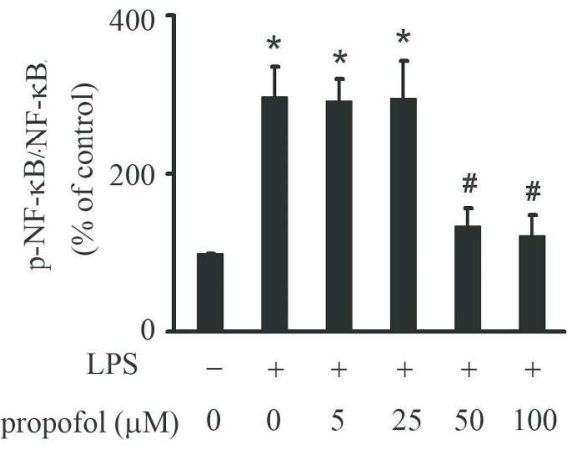

Figure 2. Propofol inhibits LPS-induced phosphorylation of NF-KB and ERK1/2. BV2 cells were treated with $1 \mu \mathrm{g} / \mathrm{ml}$ LPS for $4 \mathrm{~h}$, followed by co-incubation with different concentration $(5,25,50,100 \mu \mathrm{M})$ of propofol for the last $2 \mathrm{~h}$. (A) Equal amounts of proteins were separated by SDS-PAGE and immunoblotted with antibodies to $p-N F-K B, p-E R K 1 / 2$ and ERK1/2. (B) The protein expression ratio of $p-N F-K B$ and $\beta$-actin. The ratio in the control group was set as 1 . (C) The protein expression ratio of $p-E R K 1 / 2$ and ERK1/2. The ratio in the control group was set as 1 . ( $* P<0.05$ vs. control, \#P $<0.05$ vs. LPS treatment, $n=5$. Data are shown as mean \pm SD.)

$209 \times 250 \mathrm{~mm}(300 \times 300 \mathrm{DPI})$ 

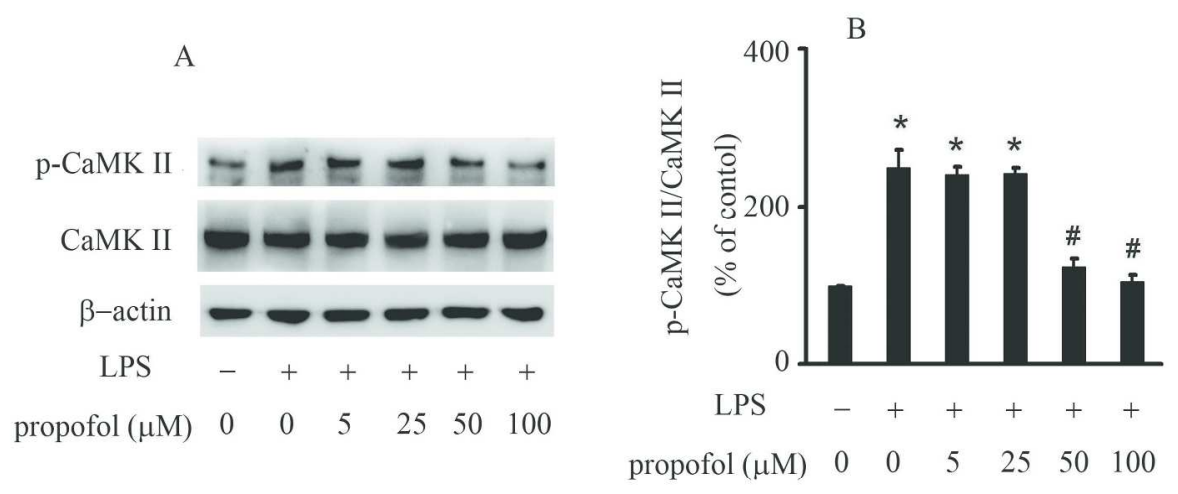

propofol $(\mu \mathrm{M}) \quad 0 \quad 0 \quad 5 \quad 25 \quad 50 \quad 100$

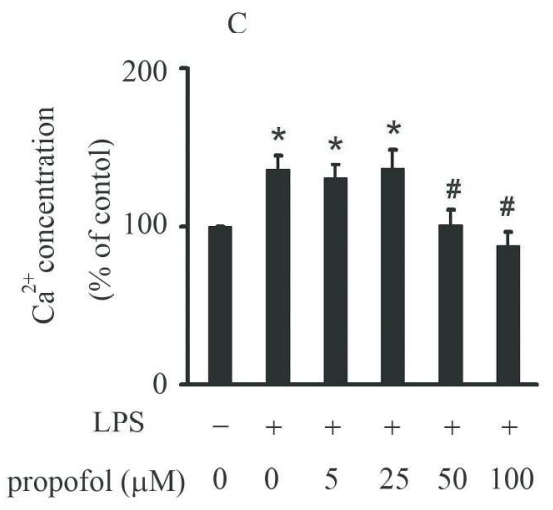

Figure 3. Propofol inhibits LPS-induced phosphorylation of CaMK II and Ca2+ accumulation. BV2 cells were treated with $1 \mu \mathrm{g} / \mathrm{ml}$ LPS for $4 \mathrm{~h}$, followed by co-incubation with different concentration $(5,25,50,100 \mu \mathrm{M})$ of propofol for the last $2 \mathrm{~h}$. (A) Equal amounts of proteins were separated by SDS-PAGE and immunoblotted with antibodies to $\mathrm{p}$-CaMK II and CaMK II. (B) The protein expression ratio of $\mathrm{p}$-CaMK II and CaMK II. The ratio in the control group was set as 1 . (C) propofol inhibited LPS-mediated Ca2+ accumulation in a concentration-depend manner. ( $* P<0.05$ vs. control, \#P $<0.05$ vs. LPS treatment, $n=5$. Data are shown as mean \pm SD.)

$209 \times 250 \mathrm{~mm}(300 \times 300 \mathrm{DPI})$ 
A

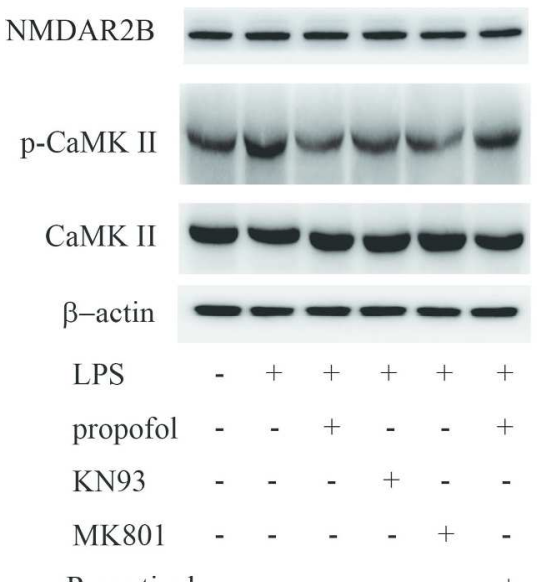

Rapastinel

C

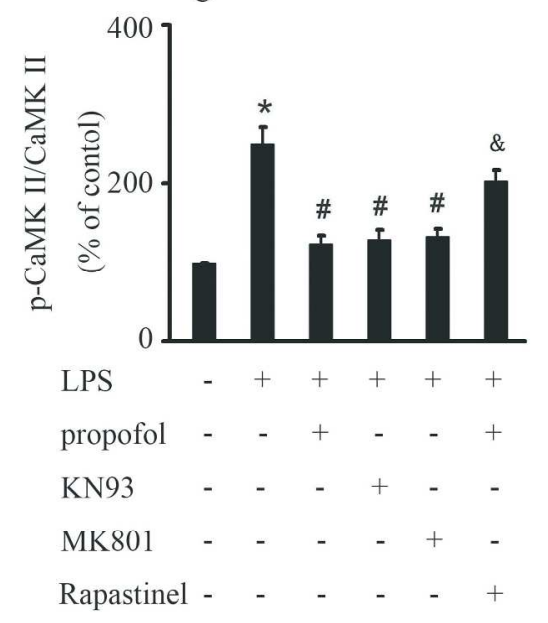

B
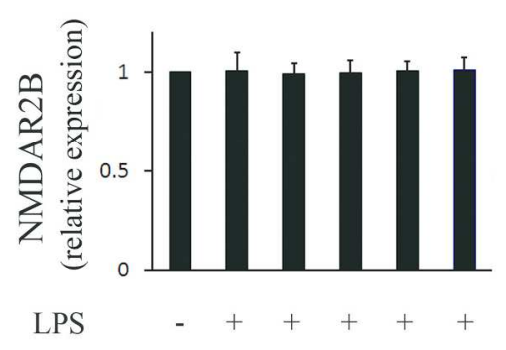

propofol

KN93

MK801

Rapastinel -

D

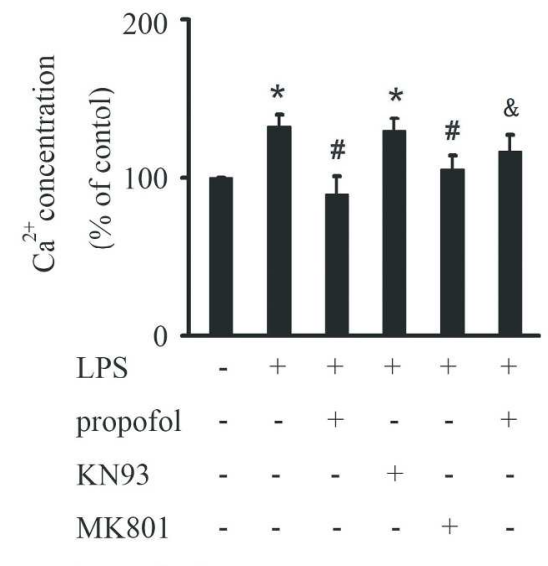

Rapastinel -

Figure 4. LPS-mediated CaMK II phosphorylation and Ca2+ accumulation, and its modulation by propofol, KN93, MK801 and rapastinel. BV2 cells were treated with $1 \mu \mathrm{g} / \mathrm{ml}$ LPS for $4 \mathrm{~h}$, followed by co-incubation with propofol, KN93, MK801 or propofol plus repastinel for the last $2 \mathrm{~h}$. (A) Equal amounts of proteins were separated by SDS-PAGE and immunoblotted with antibodies to NMDA R2B, CaMK II and p-CaMK II. (B) The protein expression ratio of NMDA R2B and $\beta$-actin. The ratio in the control group was set as 1 . (C) The protein expression ratio of $\mathrm{p}$-CaMK II and CaMK II. The ratio in the control group was set as 1. (D) propofol inhibited LPS-mediated Ca2+ accumulation, which was similar to MK801. Moreover, the effect of propofol could be counteracted by rapastinel. KN93 had no effect on cells Ca2+ concentration. ( $* P<0.05$ vs. control, $\# P<0.05$ vs. LPS treatment, \&P $<0.05$ vs. propofol treatment, $n=5$. Data are shown as mean \pm SD.)

$$
209 \times 250 \mathrm{~mm}(300 \times 300 \mathrm{DPI})
$$



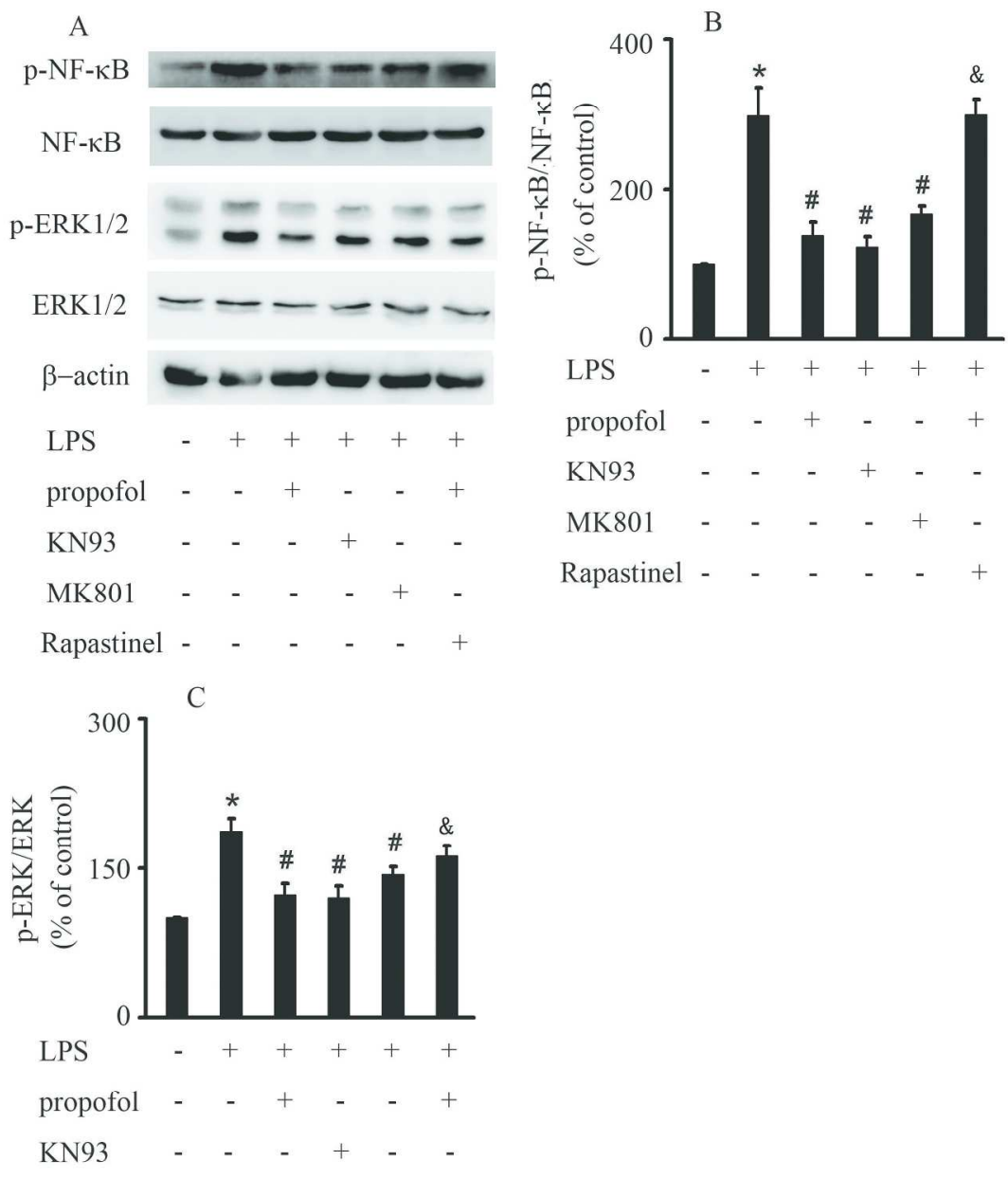

MK801

Rapastinel -

Figure 5. LPS-mediated ERK1/2 and NF-KB phosphorylation, and its modulation by propofol, KN93, MK801 and rapastinel. BV2 cells were treated with $1 \mu \mathrm{g} / \mathrm{ml}$ LPS for $4 \mathrm{~h}$, followed by co-incubation with propofol, KN93, MK801 or propofol plus repastinel for the last $2 \mathrm{~h}$. (A) Equal amounts of proteins were separated by SDS-PAGE and immunoblotted with antibodies to $\mathrm{p}-\mathrm{NF}-\mathrm{KB}, \mathrm{p}-\mathrm{ERK} 1 / 2$ and ERK1/2. (B) The protein expression ratio of $\mathrm{p}-\mathrm{NF}-\mathrm{kB}$ and $\beta$-actin. The ratio in the control group was set as 1 . (C) The protein expression ratio of $\mathrm{p}-\mathrm{ERK} 1 / 2$ and ERK $1 / 2$. The ratio in the control group was set as 1 . ( $* \mathrm{P}<0.05 \mathrm{vs}$. control, \#P $<0.05$ vs. LPS treatment, $\& P<0.05$ vs. propofol treatment, $n=5$. Data are shown as mean \pm SD.) 

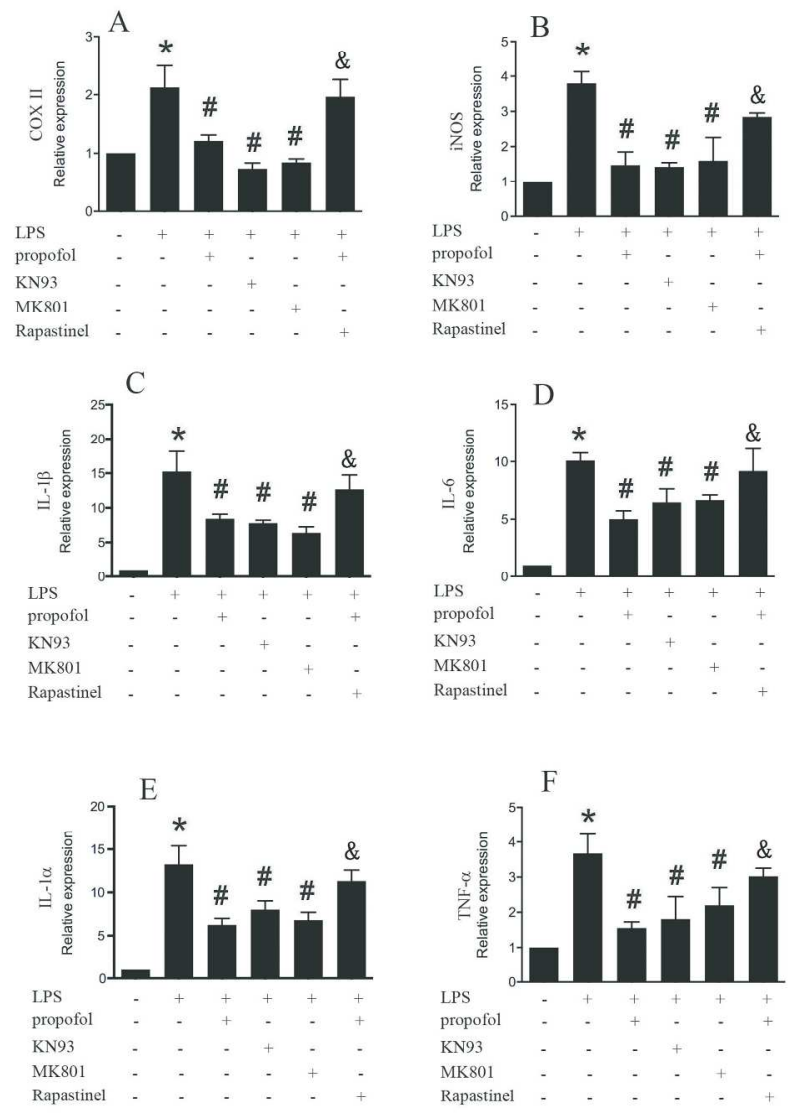

Figure 6. LPS-induced pro-inflammatory cytokines and pro-inflammatory enzymes expression, and its modulation by propofol, KN93, MK801 and rapastinel. BV2 cells were treated with $1 \mu \mathrm{g} / \mathrm{ml}$ LPS for $4 \mathrm{~h}$, followed by co-incubation with propofol, KN93, MK801 or propofol plus repastinel for the last $2 \mathrm{~h}$. (A-F)

Propofol inhibited LPS-induced the expression of pro-inflammatory cytokines and pro-inflammatory enzymes, which was similar to KN93 and MK801. Moreover, the effect of propofol could be counteracted by rapastinel. ( $* \mathrm{P}<0.05$ vs. control, $\# \mathrm{P}<0.05$ vs. LPS treatment, $\& \mathrm{P}<0.05$ vs. propofol treatment, $\mathrm{n}=5$.

Data are shown as mean \pm SD.)

$$
209 \times 250 \mathrm{~mm}(300 \times 300 \text { DPI })
$$

